\title{
The Use of Nanobiotechnology in Immunology and Vaccination
}

\author{
Reza Keikha ${ }^{1,2}$, Karim Daliri ${ }^{3}$ and Ali Jebali ${ }^{4, *}$ \\ 1 Infectious Diseases and Tropical Medicine Research Center, Resistant Tuberculosis Institute, Zahedan \\ University of Medical Sciences, Zahedan 9816743463, Iran; rezakeikha.md@gmail.com \\ 2 Department of Pathology, Faculty of Medicine, Zahedan University of Medical Sciences, \\ Zahedan 9816743463, Iran \\ 3 Department of Genetics, Shiraz University of Medical Sciences, Shiraz 1433671348, Iran; \\ karimdaliri@gmail.com \\ 4 Molecular Medicine Research Center, Research Institute of Basic Medical Sciences, \\ Rafsanjan University of Medical Sciences, Rafsanjan 7717933777, Iran \\ * Correspondence: alijebal2011@gmail.com; Tel.: +98-09900152139
}

\section{check for}

updates

Citation: Keikha, R.; Daliri, K.; Jebali, A. The Use of Nanobiotechnology in Immunology and Vaccination. Vaccines 2021, 9, 74. https://doi.org/ $10.3390 /$ vaccines 9020074

\section{Academic Editor:}

César Muñoz-Fontela

Received: 14 December 2020

Accepted: 20 January 2021

Published: 21 January 2021

Publisher's Note: MDPI stays neutral with regard to jurisdictional claims in published maps and institutional affiliations.

Copyright: (c) 2021 by the authors. Licensee MDPI, Basel, Switzerland. This article is an open access article distributed under the terms and conditions of the Creative Commons Attribution (CC BY) license (https:// creativecommons.org/licenses/by/ $4.0 /)$.

\begin{abstract}
Nanotechnology uses the unique properties of nanostructures with a size of 1 to 200 nanometers. Different nanoparticles have shown great promise for the production of new vaccines and drugs. Nanostructures can be used to deliver immunological compounds more effectively than microstructures to target sites. Different nanostructures can be applied to form a new generation of vaccines, adjuvants, and immune system drugs. The goal of nanotechnology is to better respond to a wide range of infectious and non-infectious diseases.
\end{abstract}

Keywords: nanotechnology; nanostructures; immunology; vaccination

\section{Introduction}

Biomolecules such as oligonucleotides, polysaccharides, and proteins are antigenic and all are nanometer-sized [1]. Table 1 shows the size distribution of some immunological structures [2]. In this review article, we will discuss which types of nanoparticles are good for vaccination. Their size, shape, charge, porosity, and hydrophobic properties are important. Interestingly, there is a relationship between nanoparticle size and bioactivity [3] (Table 2). We look at the role of nanotechnology in the development of vaccines and immunosuppressants. It should be noted that the field of nanotechnology is very broad and we have tried to show only immunological applications of nanomaterials. Inactive vaccines usually use adjuvants that increase the quantity and quality of cellular and humoral immune responses. Although nanoparticles enhance the delivery of antigens to the immune system, they also boost immune responses [4]. Here, we introduce some nanoparticles such as virus-like particles (VLP) and squalene-based oil-in-water emulsions such as MF59, which have been used for decades, but other nanoparticles are still in the early stages of development (Table 3).

Table 1. The size distribution of some immunological structures.

\begin{tabular}{cc}
\hline Immunological Structure & Size (nm) \\
\hline Complement & $1-5$ \\
Toll-like receptor (TLR) & $2-10$ \\
T cell receptor (TCR) & $2-10$ \\
The cluster of differentiation (CD) markers & $2-10$ \\
Antibody & $10-15$ \\
T cells & $7000-12,000$ \\
B cells & $7000-12,000$ \\
Neutrophils & $10,000-12,000$ \\
Dendritic cells & $10,000-22,000$ \\
Macrophages & $10,000-22,000$
\end{tabular}


Table 2. The relationship between nanoparticle size and bioactivity.

\begin{tabular}{ccc}
\hline Nanoparticles & Size & Bioactivity \\
\hline Dendrimer & $<5 \mathrm{~nm}$ & $\begin{array}{c}\text { Partition like small molecules and filter through the kidney } \\
\text { Escape the vasculature, infiltrate the tissues and lymphatics } \\
\text { like proteins }\end{array}$ \\
$\begin{array}{c}\text { Polymer } \\
\text { DNA polyplex }\end{array}$ & $\begin{array}{c}50-100 \mathrm{~nm} \\
\text { Liposome }\end{array}$ & $\begin{array}{c}\text { Penetrate the mucosal membranes and the skin and are taken } \\
\text { up into cells }\end{array}$ \\
\hline
\end{tabular}

Table 3. Some examples of nano-based vaccines.

\begin{tabular}{ccc}
\hline Nano-Based Vaccines & Size Range & Mechanisms \\
\hline Virus-like particles & $15-30 \mathrm{~nm}$ & $\begin{array}{c}\text { Repetitive antigen display, structural or molecular mimicry of the virus, particle } \\
\text { size-dependent tissue penetration and trafficking to lymphatics, and TLR activation }\end{array}$ \\
\hline MF59 a & $150-200 \mathrm{~nm}$ & $\begin{array}{c}\text { Neutrophil, monocyte, and DC recruitment, antigen uptake, and the induction of } \\
\text { humoral and TH1-type immune responses }\end{array}$ \\
\hline W805EC ${ }^{\text {b }}$ & $200-400 \mathrm{~nm}$ & $\begin{array}{c}\text { Antigen uptake by and activation of epithelial cells and DCs, TLR2 and TLR4 } \\
\text { activation, local cytokine production, mucosal antibody responses, and TH1, TH2, } \\
\text { and TH17 cell responses }\end{array}$ \\
\hline PLGA $^{\mathrm{c}}$ & $100-200 \mathrm{~nm}$ & Encapsulation for sustained local antigens and co-mediator release \\
\hline Nanogel & $30-40 \mathrm{~nm}$ & $\begin{array}{c}\text { Antigen entrapment in a hydrated nanogel matrix for slow release, delivery to } \\
\text { APCs, and induction of tumor-specific T cells and antibody responses }\end{array}$ \\
\hline Cationic liposomes & $200-1000 \mathrm{~nm}$ & $\begin{array}{c}\text { Encapsulation and targeted antigen delivery or uptake by APCs, and recruitment of } \\
\text { monocytes to the injection site }\end{array}$ \\
\hline
\end{tabular}

${ }^{\mathrm{a}}$ : MF59 is an immunologic adjuvant that uses a derivative of shark liver oil called squalene, ${ }^{\mathrm{b}}:$ W805EC is an oil-in-water nano-emulsionbased adjuvant for an intranasally delivered vaccine, ${ }^{c}$ : poly(lactic-co-glycolic acid).

\section{VLP-Based Vaccines}

VLPs are very diverse nanoparticles that range in size from 20 to 150 nanometers. There are several benefits to using VLPs, including unique nanometer size, symmetrical shape, uniformity, and stable structure [5]. Several applications for VLPs have been reported such as vaccination against infectious diseases and even cancer. Recently, protection against chronic inflammation diseases, such as high blood pressure, Alzheimer's disease, and rheumatoid arthritis by VLPs have been reported. Interestingly, VLPs have also been used in the preparation of vaccines against drug addiction [6].

In terms of vaccination, VLPs are divided into two classes: (a) VLPs that are subunits of viral surface proteins [7]; (b) artificial VLPs produced by chemical synthesis [8,9]. Furthermore, VLPs can be distinguished from viruses by their lack of genetic material and their inability to reproduce or perform genetic recombination. More than 20 to 30 different VLPs are currently at the clinical or pre-clinical stage [10]. Although VLPs can be prepared without modification or genetic engineering, they can be conjugated with antigenic peptides or ligands [11].

Toll-like receptor (TLR) ligands, cell receptors, or other biologically active mediators can also be linked to VLPs to enhance their efficacy. In a human clinical trial, a VLP was loaded with synthetic A-type CpG-oligonucleotides (CpGODNs) and peptide epitopes derived from melanoma-associated antigens, such as melanoma antigen recognized by T cells 1 (MART1). It has been shown that this VLP can activate multifunctional central memory T cells and cytotoxic T lymphocytes (CTLs) and secretes tumor necrosis factor- $\alpha$ (TNF), interferon- $\gamma($ IFN $\gamma)$, and interleukin 2 (IL-2). These viral nanoparticles have been uptaken more by antigen-processing cells (APCs) [12].

It is noteworthy that small nonenveloped VLPs (size 25 to 40 nanometers) overcome better tissue barriers and reach the lymph nodes. Larger VLPs (>100 nanometers) typically accumulate at the injection site and hardly reach the lymph nodes. Nanoparticles also 
appear to be more suitable for targeting cells than microparticles [13]. For example, when nanoparticles are coated with CD209 monoclonal antibodies, they can easily bind to dendritic cells (DC) better than microparticles. While most extracellular proteins are processed through the MHC class II pathway, the VLP nanoparticles are processed in both MHC class I and II, leading to the proliferation of both $\mathrm{CD} 4^{+} \mathrm{T}$ cells and $\mathrm{CD} 8^{+} \mathrm{T}$ cells $[14,15]$ (Figure 1).
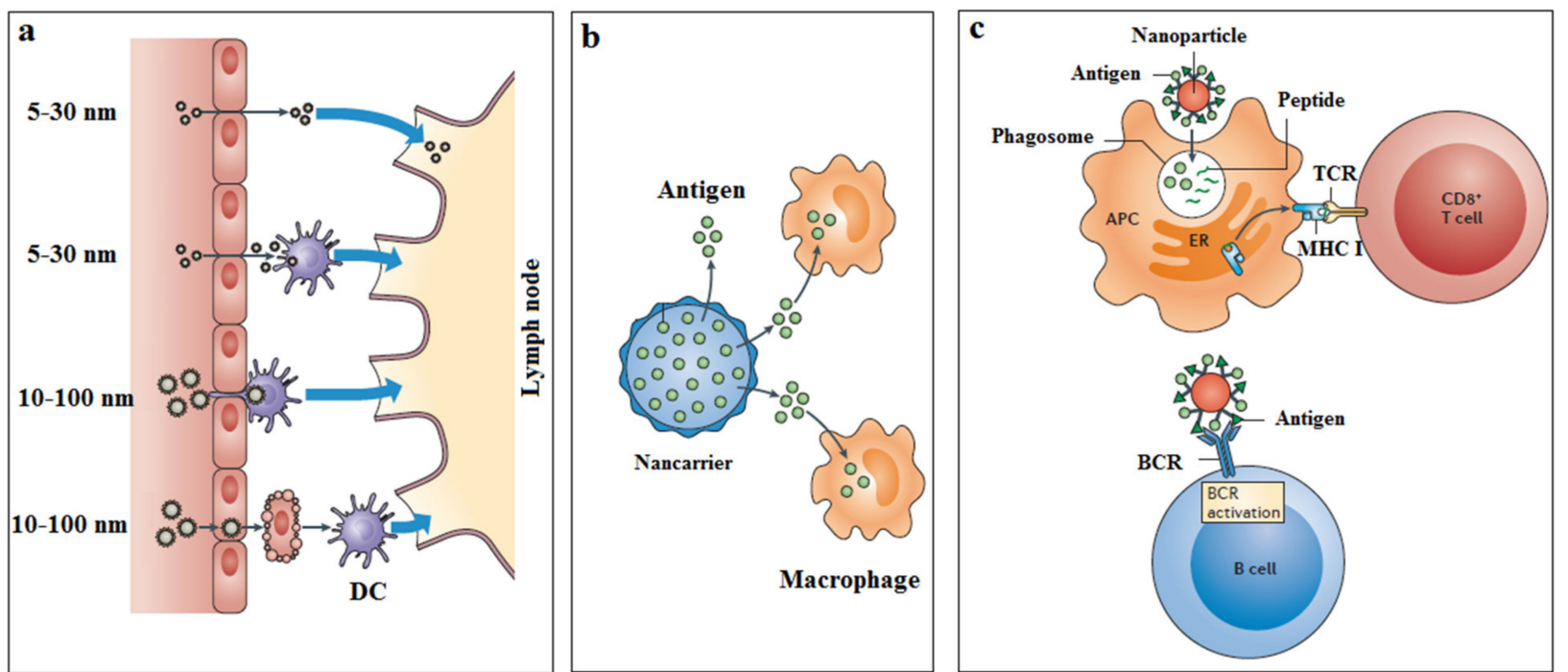

Figure 1. The delivery of nanoparticles across biological barriers and access to the lymphatics in different ways (a). The release of vaccine antigen to macrophage; (b) a depot effect, which promotes the persistence, the stability, the conformational integrity, and the gradual release of vaccine antigens. The activation of B cells and T cells by nanoparticles (c) by TLR, MHC class I, TCR, and BCR. APC, antigen-processing cell; DC, dendritic cell; TLR, Toll-like receptor; TCR, T cell receptor; BCR, B cell receptor.

Two VLP-based vaccines are currently licensed. One prevents the hepatitis B virus (HBV) and decreases the risk of hepatic carcinoma [16,17], and the other prevents the human papillomavirus from causing cervical cancer [18]. The HBV vaccine with alum adjuvants has a major limitation. Alum mainly activates T-helper 2 (TH2) and it cannot activate TH1 [19]. In a recently developed HPV vaccine, monophosphoryl A (MPL) lipid A added to induce TH1 and CTLs [20]. Although current VLP-based vaccines are effective, they also have some limitations [21]. There is insufficient evidence to support the safety of vaccination programs, which calls for additional studies. VLPs and other nanoparticle-based technologies offer novel solutions for the powerful and long-term induction of humoral and cellular immune responses. They are also useful for protection and prevention against chronic infections and highly mutable infections such as influenza and coronavirus $[6,22,23]$.

\section{Artificial VLP}

Developing artificial VLPs using lipopeptide monomers to strengthen and stabilize the three-dimensional structure of protein antigens is a novel strategy. An artificial VLP does not require recombinant DNA technology or the expression and purification of monomer proteins. One example of this platform is an artificial VLP for gp120 HIV. It displays a peptide-mimetic epitope derived from the V3-variable loop of gp120 HIV [24]. This VLP can be connected to different MHC class II molecules and activates TLR2. Interestingly, the immunization of New Zealand white rabbits with these artificial VLPs has led to the production of neutralizing antibodies $[25,26]$. 


\section{Nanoparticle-Based Vaccine Carrier}

Several types of nanoparticles have been applied as vaccine carriers to trap specific antigens. Examples of nanoparticles used as carriers in vaccination are poly (lactide-glycolide) nanoparticles (PLGA) [27], hydrogel polymers or "nanogels" [28], cationic liposomes [29], and cholesterol-bearing hydrophobized pullulan (CHP) [30]. In nanotechnology, polymers have also been utilized as nanospheres, nanoparticles, and nanocapsules [31]. PLGA vaccine carriers are widely tested in animal models and clinical applications as a matrix to be able to release drugs gradually [32]. In vaccine production, pegylated PLGA (150 to 200 $\mathrm{nm}$ ) is used to encapsulate the hepatitis B surface antigen (HBsAg) [33]. For example, a heat-degradable hydrogel consisting of pegylated PLGA (less than $100 \mathrm{~nm}$ ) was injected subcutaneously in mice to release HBsAg at the injection site. Biodegradable polymer nanoparticles have also been shown to be safe and biocompatible for application in vaccine technology [34-36].

\section{Self Assemble Peptide Nanoparticles (SAPNs)}

SPANs are created by the algorithmization of structural proteins to create a platform with repeating units [37]. The novel structure, expressed in Escherichia coli, has a two-part polypeptide chain that eventually forms a nanometer structure [38]. Nearly 180 peptide units are placed together as a nanoparticle and can stimulate the immune system. The scaffold shows antigens and activates immune cells, leading to a significant increase in the production of antibodies [39]. SAPNs can be used to produce a wide range of different antigens including aqueous peptide annular epitopes, and can successfully produce antibodies. This structure has been used to prepare vaccines for the acute respiratory syndrome coronavirus (SARS-CoV) and avian influenza virus [38,40].

\section{Cationic Liposomes}

Cationic liposomes (typically with a particle diameter of 200 to $1000 \mathrm{~nm}$ depending on the formulation) are used to encapsulate the antigens. They absorb antigens and release them into immune cells for a long time. The positive charge and lipid composition improve their efficiency. The used cationic lipids include quaternary ammonium compounds (dimethyl dioctadecyl ammonium bromide (DDA)), 1,2-dioleoyl-3-trimethyl-ammonium propane (DOTAP), cholesterol derivatives (dimethylaminoethanhanecarbamoyl-cholesterol), imidazolium compounds 1-[2-(oleoyloxy) ethyl]-2-oleyl-3-(2-hydroxyethyl) imidazolinium chloride (DOTIM)), and diC14 -amidine-based compounds, as well as other immunostimulants such as trehalose dibehenate (TDB) which is a synthetic analog of trehalose dimycolate [29,41].

\section{Nano-Emulsion}

Nano-emulsions are a mixture of water in oil and are composed of solvents and surfactants. An example of a nano-emulsion is MF59 which is composed of squalene oil in combination with polymorphic 80 (Tween 80 ) and sorbitan triolate (Span 85) [42]. In Europe, the MF59 vaccine is licensed for use in influenza vaccines and can be intramuscularly administered [43]. Its functional mechanisms appear to include increased antigen uptake, the release of inflammatory cytokines, accumulation of monocytes, and granulocytes at the injection site. MF59 is better than alum because it provides both humoral and cellular immune responses. Increased reactivity and pain at the injection site have been described after MF59 administration. This has been attributed to increased inflammation due to enhanced immune response [44-47].

W805EC nano-emulsion is composed of soybean oil and has been intramuscularly tested in animals and humans, resulting in a strong mucosal, humoral, and cellular immune response. The unique activity of this type of nano-emulsion is to maintain the structure and their positive charge, facilitating the connection to the mucosal membrane. Their size and the positive potential coefficient of nano-emulsion lead to penetrating the mucosal layer and binding to the cell membrane. Due to the high efficiency of nano molecules, they can 
be used to prepare vaccines for a variety of viruses, bacteria, and fungi. Furthermore, nanoemulsions have no toxicity according to extensive human and animal experiments $[48,49]$.

\section{Other Nanoparticles}

In addition to the above nanostructures, researchers are testing other intelligent nanostructures for use in vaccines and immunology. For example, calcium phosphate or hydroxyapatite nanoparticles can be a good platform for vaccination [50]. Specialized nano-platforms can also be made using plasmids and DNA technology [51,52]. A new strategy in vaccine design is to target B-cells by derivatizing the nanoparticle carrier with TLR ligands [53]. The surface manipulation [54,55] and the use of detector molecules such as aptamers [56] are examples of targeting. Of course, each method has its advantages and limitations [57]. Another technology is bacterial outer membrane vesicles (OMVs)based vaccines [58], presenting the antigenic stable chimeric fusion protein of the H1-type haemagglutinin (HA) of influenza A virus and the receptor-binding domain (RBD) of MERS-CoV (OMVs-H1/RBD). The OMVs-based vaccines presenting viral antigens provide a safe and reliable approach to protect against two different viral infections [59].

In addition to the stimulation of the immune system, nanotechnology can be used therapeutically to inhibit harmful immune responses that occur in allergies, autoimmunity, and transplant rejection [60]. Table 4 shows the immunosuppressive effects of some nanoparticles [61]. It has been shown that fullerene (C60) has immunosuppressive effects. C60 molecules are made up exclusively of carbon and are commonly used in nanotechnology for electronics, paints, and polymer composites. When they are incubated with mast cells, they reduce IgE-mediated signaling, ROS production, and degranulation. In the anaphylaxis mouse model, C60 prevents the secretion of histamine and prevents a decrease in body temperature, which usually occurs in mice after an allergy challenge. When C60 molecules are made like cylinders, they are called carbon nanotubes (CNTs) and are typically about 10 nanometers in diameter and several micrometers in length. This structure can be formed as single-walled or multi-walled pipes. Furthermore, it has been revealed that they have immunosuppressive effects. DCs exposed to lipopolysaccharides (LPS) and single-walled CNTs were less able to promote proliferation of T cells than DCs that were exposed to LPS alone. The mechanisms for the effect of single-walled CNTs on DC performance are not fully elucidated [62].

Table 4. The immunosuppressive effects of some nanoparticles.

\begin{tabular}{|c|c|c|c|c|}
\hline Nanoparticles & Size Range & Mechanisms & Medical Application & Current Use \\
\hline Fullerenes & $0.5-1 \mathrm{~nm}$ & $\begin{array}{l}\text { Suppression of mast cell and } \\
\text { basophil degranulation }\end{array}$ & Allergy & In mice and in vitro \\
\hline SWCNT $^{a}$ & $\begin{array}{c}\text { 1-4 nm diameter; } \\
1000-3000 \text { nm length }\end{array}$ & Suppression of DC function & Inhalation exposure & In mice \\
\hline MWCNT $^{b}$ & $\begin{array}{l}\text { 10-20 nm diameter; } \\
5000-15000 \mathrm{~nm} \text { length }\end{array}$ & $\begin{array}{l}\text { Suppression of T cell } \\
\text { proliferation and function }\end{array}$ & Inhalation exposure & In mice \\
\hline
\end{tabular}

a: single-wall carbon nanotube, ${ }^{b}$ : multi-wall carbon nanotube.

\section{Conclusions}

Nanotechnology is currently used for preventive and therapeutic applications. In the future, the use of nanoparticles with unique immunological properties will enable researchers to customize immune responses in new and unexpected ways. The size, shape, porosity, and hydrophobicity of the nanoparticles are important. Activation of CTL cells by nanoparticles can target tumors or virus-infected cells. Nanoparticles can be surrounded by viral antigens to enhance CTL activity. They also produce cytokines such as GM-CSF, IL-12, and IL-15. We can also use "suppressive nanoparticles" to control autoimmune diseases and prevent disease progression. In addition to the therapeutic applications of nanotechnology, nanosensors can help us to detect immune system diseases and discover 
new drugs. These emerging technologies offer new ways to differentiate immune cells and balance T-helper and T-Reg cells. These methods may also provide more effective medications in the future to regulate the immune system and reduce side effects. Briefly, nanotechnology will continue to provide insights into the nature of the immune response. The use of nanotechnology in immunology may also influence new strategies for the prevention or treatment of human diseases.

Author Contributions: R.K., review and editing; A.J. and K.D.; original draft preparation and supervision. All authors have read and agreed to the published version of the manuscript.

Funding: This research received no external funding.

Institutional Review Board Statement: Not applicable.

Informed Consent Statement: Not applicable.

Acknowledgments: We thank Vladimir Temchura from the Institute of Clinical and Molecular Virology, Friedrich-Alexander-University Erlangen-Nürnberg, 91054 Erlangen, Germany to review this article and giving some valuable comments.

Conflicts of Interest: The authors declare no conflict of interest.

\section{References}

1. Jebali, A.; Nayeri, E.K.; Roohana, S.; Aghaei, S.; Ghaffari, M.; Daliri, K.; Fuente, G. Nano-carbohydrates: Synthesis and application in genetics, biotechnology, and medicine. Adv. Colloid Interface Sci. 2017, 240, 1-14. [CrossRef] [PubMed]

2. Reth, M. Matching cellular dimensions with molecular sizes. Nat. Immunol. 2013, 14, 765-767. [CrossRef] [PubMed]

3. McClements, D.J. Encapsulation, protection, and delivery of bioactive proteins and peptides using nanoparticle and microparticle systems: A review. Adv. Colloid Interface Sci. 2018, 253, 1-22. [CrossRef] [PubMed]

4. Smith, D.M.; Simon, J.K.; Baker, J.R., Jr. Applications of nanotechnology for immunology. Nat. Rev. Immunol. 2013, 13, 592-605. [CrossRef]

5. Elsayed, H.; Nabi, G.; McKinstry, W.J.; Khoo, K.K.; Mak, J.; Salazar, A.M.; Tenbusch, M.; Temchura, V.; Überla, K. Intrastructural help: Harnessing $\mathrm{T}$ helper cells induced by licensed vaccines for improvement of HIV Env antibody responses to virus-like particle vaccines. J. Virol. 2018, 92. [CrossRef]

6. Jennings, G.T.; Bachmann, M.F. Immunodrugs: Therapeutic VLP-based vaccines for chronic diseases. Annu. Rev. Pharmacol. Toxicol. 2009, 49, 303-326. [CrossRef] [PubMed]

7. Noad, R.; Roy, P. Virus-like particles as immunogens. Trends Microbiol. 2003, 11, 438-444. [CrossRef]

8. Boato, F.; Thomas, R.M.; Ghasparian, A.; Freund-Renard, A.; Moehle, K.; Robinson, J.A. Synthetic virus-like particles from self-assembling coiled-coil lipopeptides and their use in antigen display to the immune system. Angew. Chem. 2007, 46, 9015-9018. [CrossRef] [PubMed]

9. Zeltins, A. Construction and characterization of virus-like particles: A review. Mol. Biotechnol. 2013, 53, 92-107. [CrossRef]

10. Kushnir, N.; Streatfield, S.J.; Yusibov, V. Virus-like particles as a highly efficient vaccine platform: Diversity of targets and production systems and advances in clinical development. Vaccine 2012, 31, 58-83. [CrossRef]

11. Buonaguro, L.; Tagliamonte, M.; Tornesello, M.L.; Buonaguro, F.M. Developments in virus-like particle-based vaccines for infectious diseases and cancer. Expert Rev. Vaccines 2011, 10, 1569-1583. [CrossRef] [PubMed]

12. Goldinger, S.M.; Dummer, R.; Baumgaertner, P.; Mihic-Probst, D.; Schwarz, K.; Hammann-Haenni, A.; Willers, J.; Geldhof, C.; Prior, J.O.; Kündig, T.M. Nano-particle vaccination combined with TLR-7 and-9 ligands triggers memory and effector CD $8+$ T-cell responses in melanoma patients. Eur. J. Immunol. 2012, 42, 3049-3061. [CrossRef] [PubMed]

13. Cubas, R.; Zhang, S.; Kwon, S.; Sevick-Muraca, E.M.; Li, M.; Chen, C.; Yao, Q. Virus-like particle (VLP) lymphatic trafficking and immune response generation after immunization by different routes. J. Immunother. 2009, 32, 118. [CrossRef] [PubMed]

14. Manolova, V.; Flace, A.; Bauer, M.; Schwarz, K.; Saudan, P.; Bachmann, M.F. Nanoparticles target distinct dendritic cell populations according to their size. Eur. J. Immunol. 2008, 38, 1404-1413. [CrossRef] [PubMed]

15. Reddy, S.T.; Van Der Vlies, A.J.; Simeoni, E.; Angeli, V.; Randolph, G.J.; O’Neil, C.P.; Lee, L.K.; Swartz, M.A.; Hubbell, J.A. Exploiting lymphatic transport and complement activation in nanoparticle vaccines. Nat. Biotechnol. 2007, 25, 1159-1164. [CrossRef] [PubMed]

16. Douglas, R.G. The heritage of hepatitis B vaccine. JAMA 1996, 276, 1796-1798. [CrossRef]

17. Hilleman, M.; McAleer, W.; Buynak, E.; McLean, A. The preparation and safety of hepatitis B vaccine. J. Infect. 1983, 7, 3-8. [CrossRef]

18. Saslow, D.; Castle, P.E.; Cox, J.T.; Davey, D.D.; Einstein, M.H.; Ferris, D.G.; Goldie, S.J.; Harper, D.M.; Kinney, W.; Moscicki, A.B. American Cancer Society Guideline for human papillomavirus (HPV) vaccine use to prevent cervical cancer and its precursors. CA Cancer J. Clin. 2007, 57, 7-28. [CrossRef] 
19. Kool, M.; Fierens, K.; Lambrecht, B.N. Alum adjuvant: Some of the tricks of the oldest adjuvant. J. Med Microbiol. 2012, 61, 927-934. [CrossRef]

20. Azimi, A.; Heidarian, S.; Zamani, H.; Taleghani, N.; Dehghani, M.; Seyedjafari, E. Optimized dose of synthetic analogues of Monophosphoryl lipid A as an effective alternative for formulating recombinant human papillomavirus vaccine. Biologicals 2020, 68, 60-64. [CrossRef]

21. Dai, S.; Wang, H.; Deng, F. Advances and challenges in enveloped virus-like particle (VLP)-based vaccines. J. Immunol. Sci. 2018, 2, 36-41.

22. Chang, L.-J.; Dowd, K.A.; Mendoza, F.H.; Saunders, J.G.; Sitar, S.; Plummer, S.H.; Yamshchikov, G.; Sarwar, U.N.; Hu, Z.; Enama, M.E. Safety and tolerability of chikungunya virus-like particle vaccine in healthy adults: A phase 1 dose-escalation trial. Lancet 2014, 384, 2046-2052. [CrossRef]

23. Mohsen, M.O.; Zha, L.; Cabral-Miranda, G.; Bachmann, M.F. Major findings and recent advances in virus-like particle (VLP)-based vaccines. In Seminars in Immunology; Academic Press: Cambridge, MA, USA, 2017; Volume 34, pp. 123-132.

24. Purwar, M.; Pokorski, J.K.; Singh, P.; Bhattacharyya, S.; Arendt, H.; DeStefano, J.; La Branche, C.C.; Montefiori, D.C.; Finn, M.; Varadarajan, R. Design, display and immunogenicity of HIV1 gp120 fragment immunogens on virus-like particles. Vaccine 2018, 36, 6345-6353. [CrossRef]

25. Wang, B.-Z.; Liu, W.; Kang, S.-M.; Alam, M.; Huang, C.; Ye, L.; Sun, Y.; Li, Y.; Kothe, D.L.; Pushko, P. Incorporation of high levels of chimeric human immunodeficiency virus envelope glycoproteins into virus-like particles. J. Virol. 2007, 81, 10869-10878. [CrossRef] [PubMed]

26. Karpenko, L.I.; Nekrasova, N.A.; Ilyichev, A.A.; Lebedev, L.R.; Ignatyev, G.M.; Agafonov, A.P.; Zaitsev, B.N.; Belavin, P.A.; Seregin, S.V.; Danilyuk, N.K. Comparative analysis using a mouse model of the immunogenicity of artificial VLP and attenuated Salmonella strain carrying a DNA-vaccine encoding HIV-1 polyepitope CTL-immunogen. Vaccine 2004, 22, 1692-1699. [CrossRef]

27. Johansen, P.; Men, Y.; Merkle, H.P.; Gander, B. Revisiting PLA/PLGA microspheres: An analysis of their potential in parenteral vaccination. Eur. J. Pharm. Biopharm. 2000, 50, 129-146. [CrossRef]

28. Ferreira, S.A.; Gama, F.M.; Vilanova, M. Polymeric nanogels as vaccine delivery systems. Nanomed. Nanotechnol. Biol. Med. 2013, 9, 159-173. [CrossRef]

29. Christensen, D.; Korsholm, K.S.; Rosenkrands, I.; Lindenstrøm, T.; Andersen, P.; Agger, E.M. Cationic liposomes as vaccine adjuvants. Expert Rev. Vaccines 2007, 6, 785-796. [CrossRef]

30. Uenaka, A.; Wada, H.; Isobe, M.; Saika, T.; Tsuji, K.; Sato, E.; Sato, S.; Noguchi, Y.; Kawabata, R.; Yasuda, T. T cell immunomonitoring and tumor responses in patients immunized with a complex of cholesterol-bearing hydrophobized pullulan (CHP) and NY-ESO-1 protein. Cancer Immun. Arch. 2007, 7, 7-10.

31. Letchford, K.; Burt, H. A review of the formation and classification of amphiphilic block copolymer nanoparticulate structures: Micelles, nanospheres, nanocapsules and polymersomes. Eur. J. Pharm. Biopharm. 2007, 65, 259-269. [CrossRef] [PubMed]

32. Lü, J.-M.; Wang, X.; Marin-Muller, C.; Wang, H.; Lin, P.H.; Yao, Q.; Chen, C. Current advances in research and clinical applications of PLGA-based nanotechnology. Expert Rev. Mol. Diagn. 2009, 9, 325-341. [CrossRef] [PubMed]

33. Feng, L.; Qi, X.R.; Zhou, X.J.; Maitani, Y.; Wang, S.C.; Jiang, Y.; Nagai, T. Pharmaceutical and immunological evaluation of a single-dose hepatitis B vaccine using PLGA microspheres. J. Control. Release 2006, 112, 35-42. [CrossRef] [PubMed]

34. Park, Y.-M.; Lee, S.J.; Kim, Y.S.; Lee, M.H.; Cha, G.S.; Jung, I.D.; Kang, T.H.; Han, H.D. Nanoparticle-based vaccine delivery for cancer immunotherapy. Immune Netw. 2013, 13, 177-183. [CrossRef]

35. Kreuter, J. Nanoparticle-based dmg delivery systems. J. Control. Release 1991, 16, 169-176. [CrossRef]

36. Marasini, N.; Skwarczynski, M.; Toth, I. Oral delivery of nanoparticle-based vaccines. Expert Rev. Vaccines 2014, 13, 1361-1376. [CrossRef] [PubMed]

37. Negahdaripour, M.; Golkar, N.; Hajighahramani, N.; Kianpour, S.; Nezafat, N.; Ghasemi, Y. Harnessing self-assembled peptide nanoparticles in epitope vaccine design. Biotechnol. Adv. 2017, 35, 575-596. [CrossRef]

38. Raman, S.; Machaidze, G.; Lustig, A.; Aebi, U.; Burkhard, P. Structure-based design of peptides that self-assemble into regular polyhedral nanoparticles. Nanomed. Nanotechnol. Biol. Med. 2006, 2, 95-102. [CrossRef]

39. He, B.; Ma, S.; Peng, G.; He, D. TAT-modified self-assembled cationic peptide nanoparticles as an efficient antibacterial agent. Nanomed. Nanotechnol. Biol. Med. 2018, 14, 365-372. [CrossRef]

40. Doll, T.A.; Neef, T.; Duong, N.; Lanar, D.E.; Ringler, P.; Müller, S.A.; Burkhard, P. Optimizing the design of protein nanoparticles as carriers for vaccine applications. Nanomed. Nanotechnol. Biol. Med. 2015, 11, 1705-1713. [CrossRef]

41. Ishii, N.; Fukushima, J.; Kaneko, T.; Okada, E.; Tani, K.; Tanaka, S.-I.; Hamajima, K.; Xin, K.-Q.; Kawamoto, S.; Koff, W. Cationic liposomes are a strong adjuvant for a DNA vaccine of human immunodeficiency virus type 1. Aids Res. Hum. Retrovir. 1997, 13, 1421-1428. [CrossRef]

42. O'Hagan, D.T. MF59 is a safe and potent vaccine adjuvant that enhances protection against influenza virus infection. Expert Rev. Vaccines 2007, 6, 699-710. [CrossRef] [PubMed]

43. Sahly, H.E. MF59 ${ }^{\mathrm{TM}}$ as a vaccine adjuvant: A review of safety and immunogenicity. Expert Rev. Vaccines 2010, 9, 1135-1141. [CrossRef] [PubMed]

44. Vogel, F.R.; Caillet, C.; Kusters, I.C.; Haensler, J. Emulsion-based adjuvants for influenza vaccines. Expert Rev. Vaccines 2009, 8, 483-492. [CrossRef] [PubMed] 
45. Podda, A. The adjuvanted influenza vaccines with novel adjuvants: Experience with the MF59-adjuvanted vaccine. Vaccine 2001, 19, 2673-2680. [CrossRef]

46. Podda, A.; Del Giudice, G. MF59-adjuvanted vaccines: Increased immunogenicity with an optimal safety profile. Expert Rev. Vaccines 2003, 2, 197-204. [CrossRef]

47. Suleiman, E.; Damm, D.; Batzoni, M.; Temchura, V.; Wagner, A.; Überla, K.; Vorauer-Uhl, K. Electrostatically Driven Encapsulation of Hydrophilic, Non-Conformational Peptide Epitopes into Liposomes. Pharmaceutics 2019, 11, 619. [CrossRef]

48. Stanberry, L.; Simon, J.; Johnson, C.; Robinson, P.; Morry, J.; Flack, M.; Gracon, S.; Myc, A.; Hamouda, T.; Baker, J., Jr. Safety and immunogenicity of a novel nanoemulsion mucosal adjuvant W805EC combined with approved seasonal influenza antigens. Vaccine 2012, 30, 307-316. [CrossRef]

49. Das, S.C.; Hatta, M.; Wilker, P.R.; Myc, A.; Hamouda, T.; Neumann, G.; Baker, J.R., Jr.; Kawaoka, Y. Nanoemulsion W805EC improves immune responses upon intranasal delivery of an inactivated pandemic H1N1 influenza vaccine. Vaccine 2012, 30, 6871-6877. [CrossRef]

50. Damm, D.; Rojas-Sánchez, L.; Theobald, H.; Sokolova, V.; Wyatt, R.T.; Überla, K.; Epple, M.; Temchura, V. Calcium phosphate nanoparticle-based vaccines as a platform for improvement of HIV-1 Env antibody responses by intrastructural help. Nanomaterials 2019, 9, 1389. [CrossRef]

51. Tannig, P.; Peter, A.S.; Lapuente, D.; Klessing, S.; Damm, D.; Tenbusch, M.; Überla, K.; Temchura, V. Modulation of VaccineInduced HIV-1-Specific Immune Responses by Co-Electroporation of PD-L1 Encoding DNA. Vaccines 2020, 8, 27. [CrossRef]

52. Rashidi, M.; Jebali, A. Liposomal prodigiosin and plasmid encoding serial GCA nucleotides reduce inflammation in microglial and astrocyte cells by ATM/ATR signaling. J. Neuroimmunol. 2019, 326, 75-78. [CrossRef] [PubMed]

53. Zilker, C.; Kozlova, D.; Sokolova, V.; Yan, H.; Epple, M.; Überla, K.; Temchura, V. Nanoparticle-based B-cell targeting vaccines: Tailoring of humoral immune responses by functionalization with different TLR-ligands. Nanomed. Nanotechnol. Biol. Med. 2017, 13, 173-182. [CrossRef] [PubMed]

54. Bafghi, A.F.; Daghighi, M.; Daliri, K.; Jebali, A. Magnesium oxide nanoparticles coated with glucose can silence important genes of Leishmania major at sub-toxic concentrations. Colloids Surf. B Biointerfaces 2015, 136, 300-304. [CrossRef] [PubMed]

55. Bafghi, A.F.; Jebali, A.; Daliri, K. Silica nanowire conjugated with loop-shaped oligonucleotides: A new structure to silence cysteine proteinase gene in Leishmania tropica. Colloids Surf. B Biointerfaces 2015, 136, 323-328. [CrossRef]

56. Ayatollahi, M.; Ayatollahi, G.; Rashidi, M.; Hekmatimoghaddam, S.; Mosshafi, M.; Jebali, A.; Iman, M.; Sardo, H.S. ProdigiosinConjugated Aptamer for Attachment to the Surface of Brain Cancer Cells Mediated by Glutamate Receptor. Colloid Interface Sci. Commun. 2018, 24, 45-48. [CrossRef]

57. Barnowski, C.; Kadzioch, N.; Damm, D.; Yan, H.; Temchura, V. Advantages and Limitations of Integrated Flagellin Adjuvants for HIV-Based Nanoparticle B-Cell Vaccines. Pharmaceutics 2019, 11, 204. [CrossRef]

58. Van der Pol, L.; Stork, M.; van der Ley, P. Outer membrane vesicles as platform vaccine technology. Biotechnol. J. 2015, 10, 1689-1706. [CrossRef]

59. Shehata, M.M.; Mostafa, A.; Teubner, L.; Mahmoud, S.H.; Kandeil, A.; Elshesheny, R.; Boubak, T.A.; Frantz, R.; Pietra, L.L.; Pleschka, S. Bacterial outer membrane vesicles (omvs)-based dual vaccine for influenza a h1n1 virus and mers-cov. Vaccines 2019, 7, 46. [CrossRef]

60. Zolnik, B.S.; González-Fernández, Á.; Sadrieh, N.; Dobrovolskaia, M.A. Minireview: Nanoparticles and the immune system. Endocrinology 2010, 151, 458-465. [CrossRef]

61. Ngobili, T.A.; Daniele, M.A. Nanoparticles and direct immunosuppression. Exp. Biol. Med. 2016, 241, 1064-1073. [CrossRef]

62. Ilinskaya, A.; Dobrovolskaia, M. Immunosuppressive and Anti-Inflammatory Properties of Engineered Nanomaterials. In Handbook of Immunological Properties of Engineered Nanomaterials: Volume 3: Engineered Nanomaterials and the Immune Cell Function; World Scientific: Singapore, 2016; pp. 139-163. 